\title{
Subsurface S-type Granitoid Identification Based on Gravity and Seismic Tomography Models in Pacitan, East Java
}

\section{Identifikasi Granitoid Tipe-S Bawah Permukaan Berdasarkan Model Gravitasi dan Tomografi Seismik di Pacitan, Jawa Timur}

\author{
Joko Soesilo', Indriati Retno Palupi², Wiji Raharjo², Sutanto' ${ }^{1}$, Faris Ahad Sulistyohariyanto', \\ Kevin Gardo Bangkit Ekaristi², Fandi Budi Stiawan ${ }^{2}$ \\ ${ }^{1}$ Teknik Geologi, Fakultas Teknologi Mineral, Universitas Pembangunan Nasional "Veteran” Yogyakarta, \\ ${ }^{2}$ Teknik Geofisika, Fakultas Teknologi Mineral, Universitas Pembangunan Nasional "Veteran" Yogyakarta, \\ Jl. SWK No.104, Condongcatur, Sleman, Daerah Istimewa Yogyakarta, Indonesia, 55283 \\ *E-mail: j_soesilo@upnyk.ac.id
}

Article received: 9 November 2018, revised: 25 November 2019, accepted: 30 November 2018

DOI: $10.17146 /$ eksplorium.2018.39.2.4954

\begin{abstract}
Granitoid outcrop has been observed in Montongan, Tulakan Subdistrict, Pacitan District, East Java. Geochemically, granitoid shows peralluminous S-type granitoid which consists of comparable plagioclase and potassium feldspar leading to adamelite and granodiorite variety with andalusite, fine size corundum and cordierite inside. These modal minerals are consistent with its bulk chemical analysis result that shows alumina rich rock. Highly weathered spotted pinkish soil with remaining quartz gravels characterizes its surface. Lateritic pink soil up to more than 25 meters thick covers the granitoid body and this feature is indicative to locate its surface distribution, while its subsurface distribution is remain uncertain. The research aimed to identify granitoid subsurface distribution. To identify the subsurface body, gravity and seismic tomography models were used. According gravity model, the pluton body is $5 \mathrm{~km}$ wide which is rootless downward and seems extends eastward. Meanwhile, the north-south seismic tomographic model across Pacitan Region indicates dense solid body override the recent Java subduction zone. The body is assumed to have correlation with surface granitic rock. It supports an idea that there is a micro continent trapped beneath Southern Mountain of East Java.
\end{abstract}

Keywords: granitoid, Pacitan, S-type granite, tomography, gravity

\begin{abstract}
ABSTRAK
Singkapan granitoid telah teramati di daerah Montongan, Kecamatan Tulakan, Kabupaten Pacitan, Jawa Timur. Secara geokimia, granitoid Pacitan memperlihatkan granitoid peralumina tipe-S yang tersusun berdasarkan perbandingan plagioklas dan kalium felspar menunjuk pada varian adamelit dan granodiorit dengan andalusit, korundum halus dan kordierit di dalamnya. Mineral modal tersebut konsisten dengan hasil analisis kimia total yang menunjukkan batuan kaya alumina. Tanah berwarna merah muda yang sangat lapuk dengan kerikil sisa kuarsa menjadi ciri khas di permukaannya. Tanah laterit merah muda yang tebalnya lebih dari 25 meter menutupi tubuh granitoid tersebut dan menjadi petunjuk penyebaranya di permukaan, namun penyebaran di bawah permukaannya masih belum pasti. Penelitian ini bertujuan untuk mengetahui penyebaran granitoid di bawah permukaan. Untuk mengidentifikasi tubuh bawah permukaannya, digunakan pemodelan graviti dan tomografi seismik. Menurut model graviti tubuh pluton mempunyai lebar $5 \mathrm{~km}$ dan tampak memanjang ke arah timur yang tidak menentu ke bawahnya. Sementara itu, model tomografi seismik utara-selatan yang memotong wilayah Pacitan, menunjukkan suatu tubuh padat keras berada di atas zona subduksi Jawa saat ini. Tubuh tersebut diasumsikan memiliki hubungan dengan batuan granitoid di permukaan. Hal tersebut mendukung pendapat bahwa terdapat mikro-kontinen terperangkap di bawah Pegunungan Selatan Jawa Timur.
\end{abstract}

Kata kunci: granitoid, Pacitan, granit tipe-S, tomografi, graviti. 


\section{INTRODUCTION}

Quartz rich Paleogene-Early Neogene sedimentary formations are found along Southern Mountain of East Java Basin. Bulk bipyramidal quartz found in the dacitic tuff of Besole Formation, aged Late Paleogene. This type of quartz also composing the Jaten conglomerate, breccia and sandstone and also present in Wuni sandstone and tuff aged Early Neogene [1, 2]. Bulk number of magmatic quartz present in sedimentary formations around Pacitan portray a great influence of acidic magma sources which had been enigma for discussions about this basin. The granitoid outcrops discovered in Pacitan area may answer our wonder about source of the Late Paleogene-Early Neogene quartz rich sediments in Southern Mountain of East Java Stratigraphy $[3,4]$.

The Pacitan granitoid undergoes severe degree of weathering thus fresh rock is hardly observed. The soil up to more than 25 meters thick covers the granitoid body. To determine its surface distribution is notified by highly weathered spotted pinkish soil with remaining quartz gravels. But its subsurface distribution is remain uncertain. The research aimed to identify granitoid subsurface distribution.. Petrography, geochemistry analysis of rock samples, gravity method and seismic tomography in this study provides petrogenesis of granitoid magma and its subsurface distribution.

\section{GEOLOGY}

\section{Tertiary Stratigraphy}

Physiographically, research area is located in Pacitan Regency which is part of Southern Mountain Arc (Figure 1). The oldest formation in research area is Mandalika Formation which consists of interbedded of turbidity sandstone, volcanic breccia, tuff, and basaltic pillow lava with infrequent granitoid xenolith. Mandalika Formation interfingering with Arjosari Formation and spreads over central to western part of the area which consists of pyroclastic rock, limestone, and pumice sandstone [1, 2] (Figure 2). These two formations aged from Oligocene - Miocene which is later intruded by basaltic - dacitic intrusion in the same time and forms alteration - mineralization zone $[5,6]$.

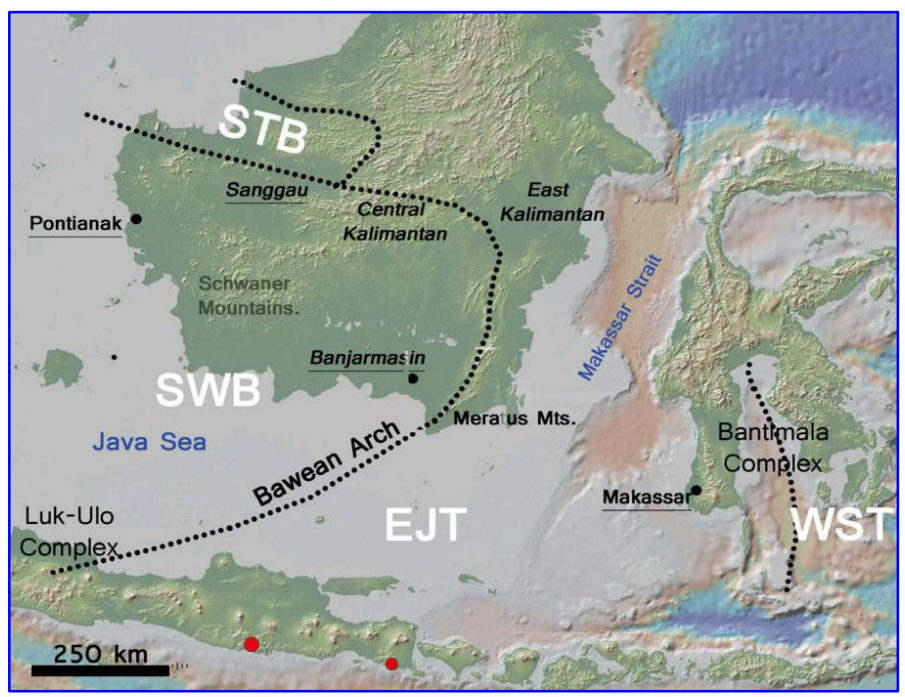

Figure 1. Overview of Central Indonesia. The red dots represent the two known granitoid outcrop of Southern java. Black dots represent boundaries between micro-continents.SWB= Soutwest Borneo terrane, EJT= East Java terrane,WST= West Sulawesi terrane. From GeoMapApp (modified from [7]). 


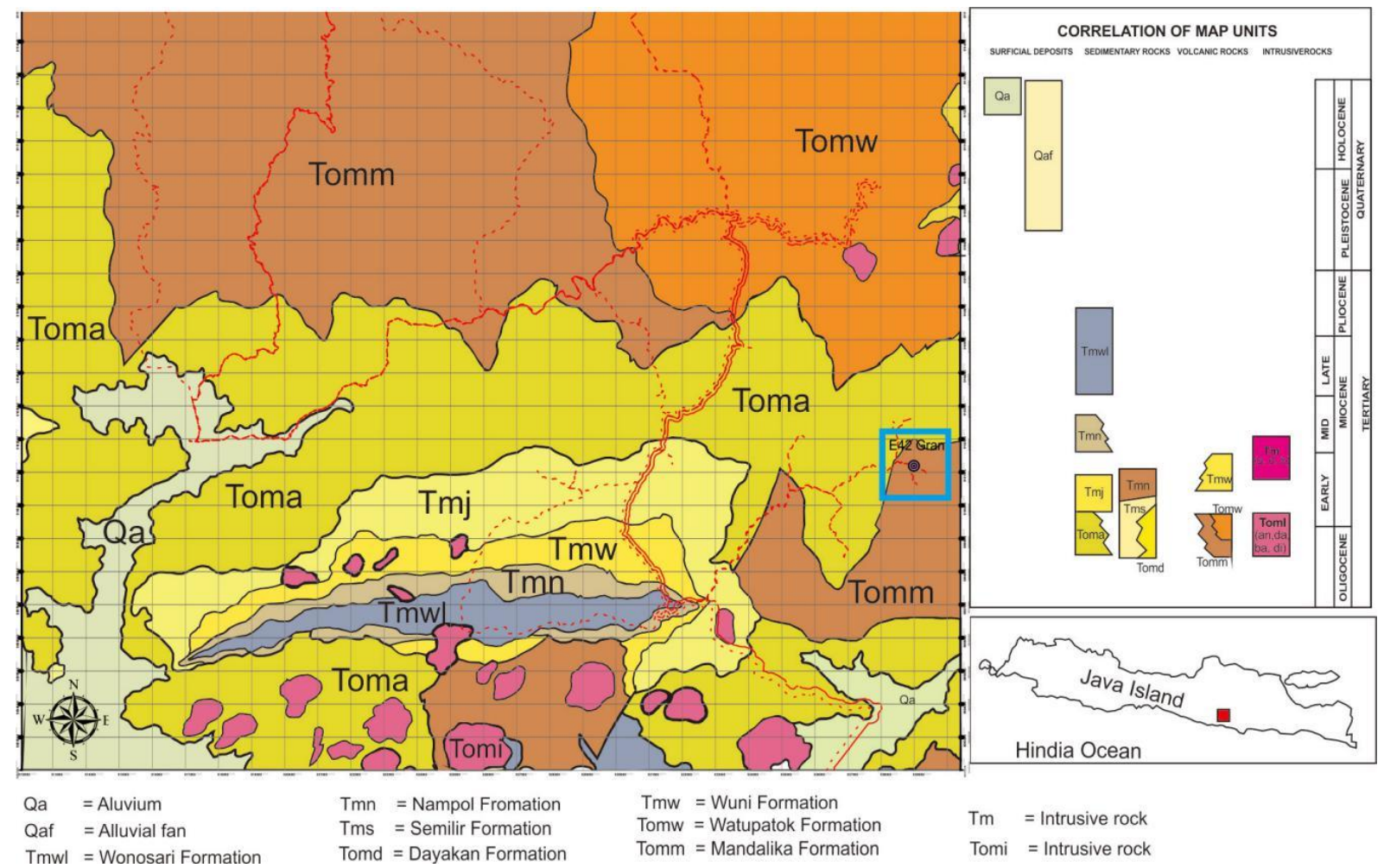

Figure 2. Stratigraphy and geological map of Pacitan District [5]. Blue square indicates the study area, while blue circle indicate sample E75-GD2 location.

Quartz-rich sandstone, conglomerates, tuffaceous sandstone, lignite, and shale were deposited in Early Miocene unconformably above volcanogenic Mandalika and Arjosari Formation. It is the Jaten Formation. Conformably lies above Jaten, Wuni Formation consists of breccia, tuff, and sandstone with intercalations of lignite and limestone deposited at the age of Early - Mid Miocene. When sea level was at its peak in Late Miocene, Punung limestone was formed and covered the pre-existing formations $[1,2]$. Karst topography is rarely seen in the research area unlike in the western part of the Southern Mountain which is very well developed due to narrow distribution. Magmatic activities began in Eocene marked by tholleiitic basalt pillow lava of Mandalika Formation. The andesiticbasaltic spectrum occurred from Eocene until Oligocene, and in the beginning of Middle Miocene, the spectrum slowly turns to rhyolitic. Middle Miocene magmatism yields calc alkaline and tholeiitic andesite, basalt, and dacite which is still continue until the end of Late Miocene [5, 6]. Younger andesitic intrusion emerged in the south part at the age of $\pm 12,07$ Ma called Sepang intrusion [6], which led to the formation of marbleized Punung limestone. The majority of faults in the research area are trending northeast-southwest and northwest-southeast. Anticline trending east-west in the central part of the area [1].

\section{Microcontinent}

From the recent concept regarding the formation of Java Island, East Java Southern Mountain is considered emerging the East Java-West Sulawesi known as Argo microcontinent $[8,9,10]$. Since the discovery of Archean zircon resides the Oligo-Miocene volcanic rock give new insight regarding the presence of Gondwana associated microcontinent as the basement of East Java Southern Mountain [8, 9, 11], which yields a 
new idea to draw separately the East Java Southern Mountain from Argo micro continent. Thus, the petrogenesis, geochemistry interpretations and then age of Pacitan Granitoid can support the existence of micro-continent.

\section{METHODOLOGY}

This research is using some methods to achieve the goal. They are petrography analysis and bulk chemical analysis along with Newtonian Method of Gravitation analysis in comparison with sufficient geological field work and hypocenter relocation and then seismic tomography.

Thin section of $0.03 \mathrm{~mm}$ thick slice rock is used to identify mineral composition, texture and structure of rocks. Sliced rock was done by diamond saw plate.

One granitoid (E75-GD2) rock were analysed by whole-rock X-ray fluorescence (XRF) spectrometry at Geolab, Centre for Geological Survey Bandung (table 1). Incomplete data result from year 2010 research in the area was used for better assessment of the granitoid chemical compounds.

The Newton Principles of gravitation states that the change in momentum of a mass will proportional to the force that works on that mass and it will work in the same direction of the force. Survey design for the gravity method in Pacitan Regency generated by placing 57 gridded points covers approximately $30 \mathrm{~km} \mathrm{x}$ $30 \mathrm{~km}$ area wide including Arjosari, Nawangan, Bandar, and Tegalombo Subdistrict. The measurement data includes gravity acceleration value and altimetry value using Gravity meter LaCoste \& Romberg Model G-1177. The raw data is then processed by several corrections such as drift correction, free air correction, latitude correction, tidal correction, free air correction, Bouguer correction, and terrain correction to yielding complete bouguer anomaly map. Upward continuity process is conducted using Oasis Montaj software. To generate 3 dimension model and cross section from complete bouguer anomaly map, addition software such as Surfer, Gravblox, and Volxer are required.

Table 1. Recent bulk chemical analysis result and previous analysis.

\begin{tabular}{crr}
\hline Oxides & \multicolumn{1}{c}{$\begin{array}{c}\text { E75-GD.2 } \\
(2017)\end{array}$} & \multicolumn{1}{c}{$\begin{array}{c}\text { Soesilo } \\
(2010)\end{array}$} \\
\hline Locality & \multicolumn{1}{r}{ Montongan } & Montongan \\
\hline $\mathrm{SiO} 2$ & $74.77 \%$ & $1.11 \%$ \\
$\mathrm{Fe} 2 \mathrm{O} 3$ & $2.07 \%$ & $0.998 \%$ \\
$\mathrm{FeO}$ & $1.86 \%$ & $11.20 \%$ \\
$\mathrm{Al}_{2} \mathrm{O}_{3}$ & $13.33 \%$ & $2 \mathrm{ppm}$ \\
$\mathrm{As}_{2} \mathrm{O}_{3}$ & $0.21 \%$ & $1.70 \%$ \\
$\mathrm{~K}_{2} \mathrm{O}$ & $0.68 \%$ & $0.15 \%$ \\
$\mathrm{MgO}_{\mathrm{TiO}}$ & $0.156 \%$ & \\
$\mathrm{SO}_{3}$ & $0.148 \%$ & \\
$\mathrm{CaO}_{2}$ & $2.21 \%$ & $0.30 \%$ \\
$\mathrm{P}_{2} \mathrm{O}_{5}$ & $0.0435 \%$ & \\
$\mathrm{Cr}_{2} \mathrm{O}_{3}$ & $0.0236 \%$ & \\
$\mathrm{CuO}_{\mathrm{SrO}}$ & $0.0055 \%$ & \\
$\mathrm{ZnO}_{\mathrm{V}} \mathrm{O}_{5}$ & $0.0054 \%$ & \\
$\mathrm{Na}_{2} \mathrm{O}$ & $0.0023 \%$ & \\
$\mathrm{Ga}_{2} \mathrm{O}_{3}$ & $0.0031 \%$ & \\
$\mathrm{MnO}_{\mathrm{Zr}}$ & $5.22 \%$ & $2.66 \%$ \\
$\mathrm{Rest}$ & $0.0018 \%$ & \\
\hline
\end{tabular}

Hypocenter Relocation is required to repositioning the quake at coordinates $\mathrm{x}, \mathrm{y}$ and depth $\mathrm{z}$ by subsurface velocity model using seismic data owned by ISC. Relocation process is conducted with the help of Matlab R2008b based on Jacobian matrix and ak135 velocity model [12]. Grid used is at the $\mathrm{x}$ coordinate is $20 \mathrm{~km}$, the y coordinate is $10 \mathrm{~km}$, while the $\mathrm{z}$ is variation from 5,10 to $20 \mathrm{~km}$ adjusted with increasing depth, the greater the depth value (z).

This research uses FMTOMO software for seismic tomography analysis. The concept of FMTOMO applies Huygens Law and 
Fermat Principle, from two basic principles of seismic software. The software is able to describe the plate boundary (Moho), crust, upper mantle. Check board manufacture and resolution test were performed to determine the input parameter corresponding to the location of research before the tomography started (Figure 3a).

\section{RESULTS AND DISCUSSION Petrography}

The outcrop of Granitoid encompasses the southeastern part of Pacitan Regency, approximately within more than 25 square kilometers vicinity Montongan village. Marks by reddish white lateritic soil up to $25 \mathrm{~m}$ thick with abundant of remaining quartz gravel, deposited near hillside (Figure 3a). Fresh outcrop is in the small river below the valley or in the form of residual boulder around the paddy field. The thick soil indicates intense weathering process and indicating had been happened for long period, probably due to the old ages of the rocks. Pacitan Granitoid mainly exhibits adamelite and granodiorite instead of granite [3]. The granitoid accompanied by upright north-south dipping quartz-feldspar vein reaching $30 \mathrm{~cm}$ thick and aplite-dacite in the form of dykes and enclaves. Adamellite appears to be white to pinkish white $(8 \%$ to $15 \%$ of color index) holocrystalline, crystal size between 6-0.2 mm, and composed of up to $30 \%$ quartz, plagioclase, k-feldspar, biotite, and relative small number of magnetite. Mandalika basalt surrounds the perimeter were reported to have granitoid xenolith indicating that the granitoids are either coeval to Besole Formation or even older.

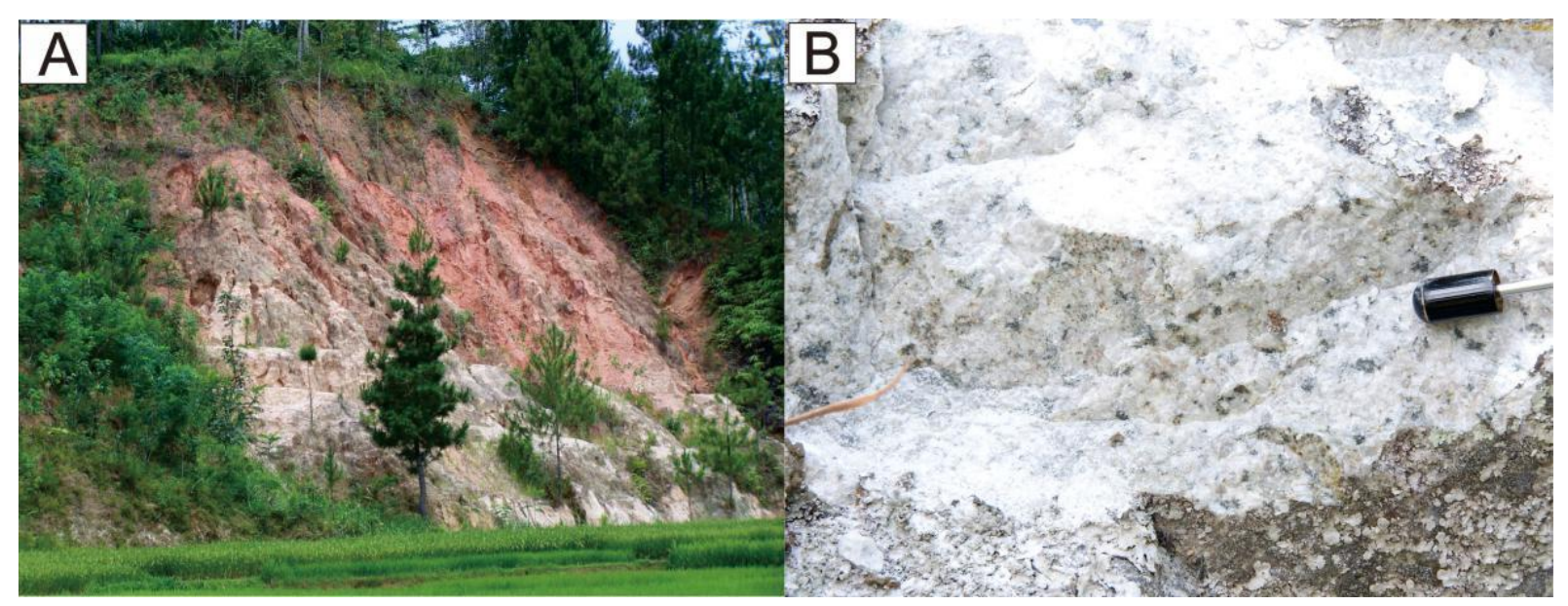

Figure 3. The figure shows outcrop of Pacitan Granitoid E75-GD2. Intense rate of weathering yields red lateritic soil (A). Fresh pinkish white boulder of adamelite with blackish biotite was partly converted to chlorite and epidote (B). 


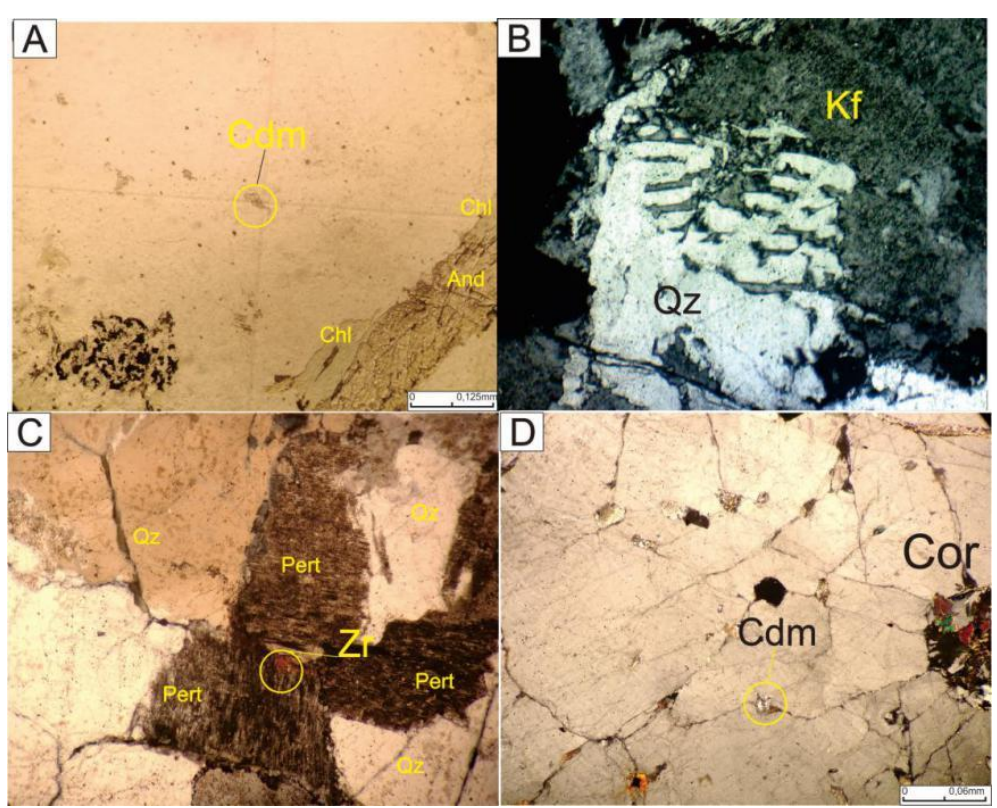

Figure 4. Photomicrographs of Pacitan adamelite show various texture and minerals. Polarized plane showing andalusite, chlorite replacing pre-existing biotite, and minute crystal of corundum (A). Graphic texture formed by quartz and k-feldspar intergrowth in cross polarized (B). Perthite texture surrounds minute zircon (C). Minute corundum and cordierite inside cracked quartz (D).

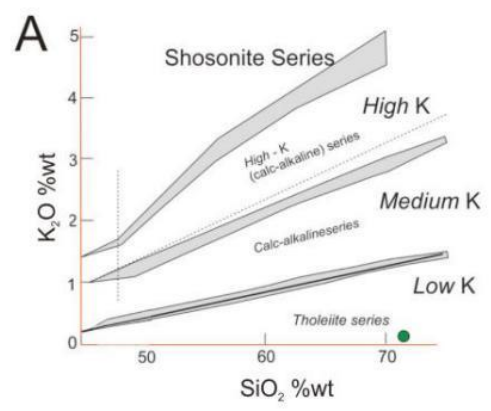

C

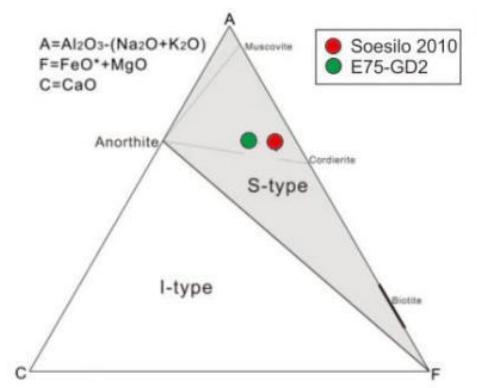

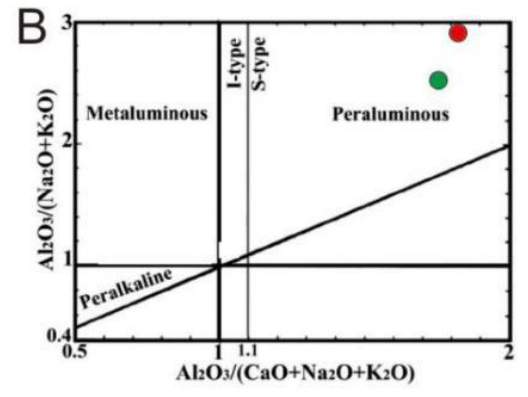

D

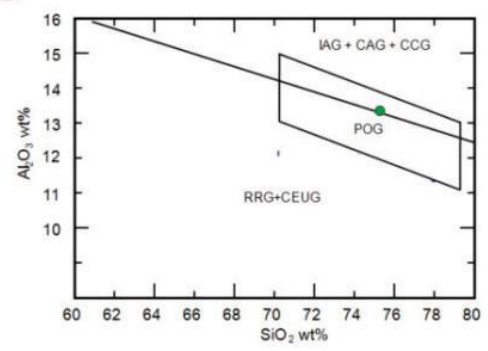

Figure 5. Geochemical discrimination diagram for granitoid analysed in this study and reported for Pacitan granitoid. The rock classified as tholeittic series [13] (A); with peraluminous chemistry [14] (B); It belongs to the type S cordierite granitoid [15] (C); and Post orogenic granitoid [14] (E).

Petrographically, adamellite shows relatively equal proportion of plagioclase and k-feldspar and sometimes excess plagioclase leading to granodiorite. They are characterized by higher number of quartz over other minerals. Graphic and granophyric texture exhibits varieties of minerals (Figure $4 \mathrm{~b}$ ) reveals the intergrowth of quartz and kfeldspar while perthite texture formed by lamellae of albite inhabits within k-feldspar (Figure 4c) marks the evidence of exolution in solid phase had occurred during dilatory 
cooling. Subsequent retrograde effects including replacement of biotite by chlorite (Figure 4a) and feldspar by sericite (Figure 4c). Preserved magmatic textures notify that there is no solid state syn-tectonic deformation

\section{Geochemistry}

Analyses were acquired from fresh rock. The LOI index acquired from the data are below 1 (previous Soesilo's data not presented) which assume that the rock still in relatively acceptable condition for interpretation, seems that the alteration did not take big part altering the minerals. High aluminum content are reflected by the presence of substantial accessory minerals including high relief andalusite (Figure 4a), altered cordierite with scattered opaque minerals (Figure 4d), and limited numbers of diminutive corundum (Figure 4a). The ratio of $(\mathrm{K}+\mathrm{Na}) / \mathrm{Al}$ from previous analysis [4] and E75-GD2 respectively are 0.389 and 0.573 , while the ratio of $(\mathrm{K}+\mathrm{Na}+2 \mathrm{Ca}) / \mathrm{Al}$ are 0.443 and 0.799. Geochemical data obtained from granitoid is compared to the previous [4], yielding the same type of peraluminous S-type granitoid (Figure 5b and 5c). Pacitan granitoid belongs to the tholeiite series (Figure 5a), marked by low pottasium content and also low quantity of K-feldpsar over plagioclase in overall granitoid body. The ratio of $\mathrm{Al}_{2} \mathrm{O}_{3}$ to $\mathrm{SiO}_{2}$ suggests that the specimen belongs to post orogenic granitoid (Figure 5d).

\section{Bouguer Anomaly}

The map (Figure 6a) exhibits varieties of gravity values, by comparing with geological field data, the granitoid body appears to have the lowest of gravity acceleration value (8.2677.4 mgal) marked by deep blue color bounded by dashed line. The weak gravity response is due to the contrast density between light granitic rock with denser intermediate to basaltic and mineralization zone. Upward Continuity has been done by 5 times within $1000 \mathrm{~m}$ interval in order to generalize the local anomaly distribution (Figure 6e). Within 4000 $\mathrm{m}$ intervals and above, red anomaly in the middle tends to fade away, while the interpreted granitoid body (blue) remains visible at $5000 \mathrm{~m}$ intervals.

Two intersect cross section lines portray the vertical distribution of the body (Figure 6a $\& 6$ b). The low density values marked by blue - purple colors are interpreted as the granitoid body (dashed red line), implies that the body is continuously distributed exceeding $10 \mathrm{~km}$ below surface. 3D model generated by Gravblock software using complete bouguer anomaly as prior data (Figure 6d). The 3D model represents clearer distribution granitoid body in the southeastern part indicated by blue to purple color $(2.4-1.8 \mathrm{~g} / \mathrm{cc})$, while green interpreted as Mandalika and Arjosari Formation.

\section{Seismic Tomography of N-S Java, across Pacitan area}

Tomography data is required to illustrate sub surface vertical continuity up to very deep level. Using Matlab R2008b to relocate the hypocenter, this effort might be done. The N$S$ vertical section (Figure 7) provided by tomography model suggest that recent subduction occurs underneath Pacitan with indication of faster seismic area (blue-bluish color) override the recent subduction. The red area interpreted as magma, while blue color that overrides the red, interpreted as solid dense material derived from portion of continental crystalline formation and it is assumed to be the origin of Pacitan granitoid. 


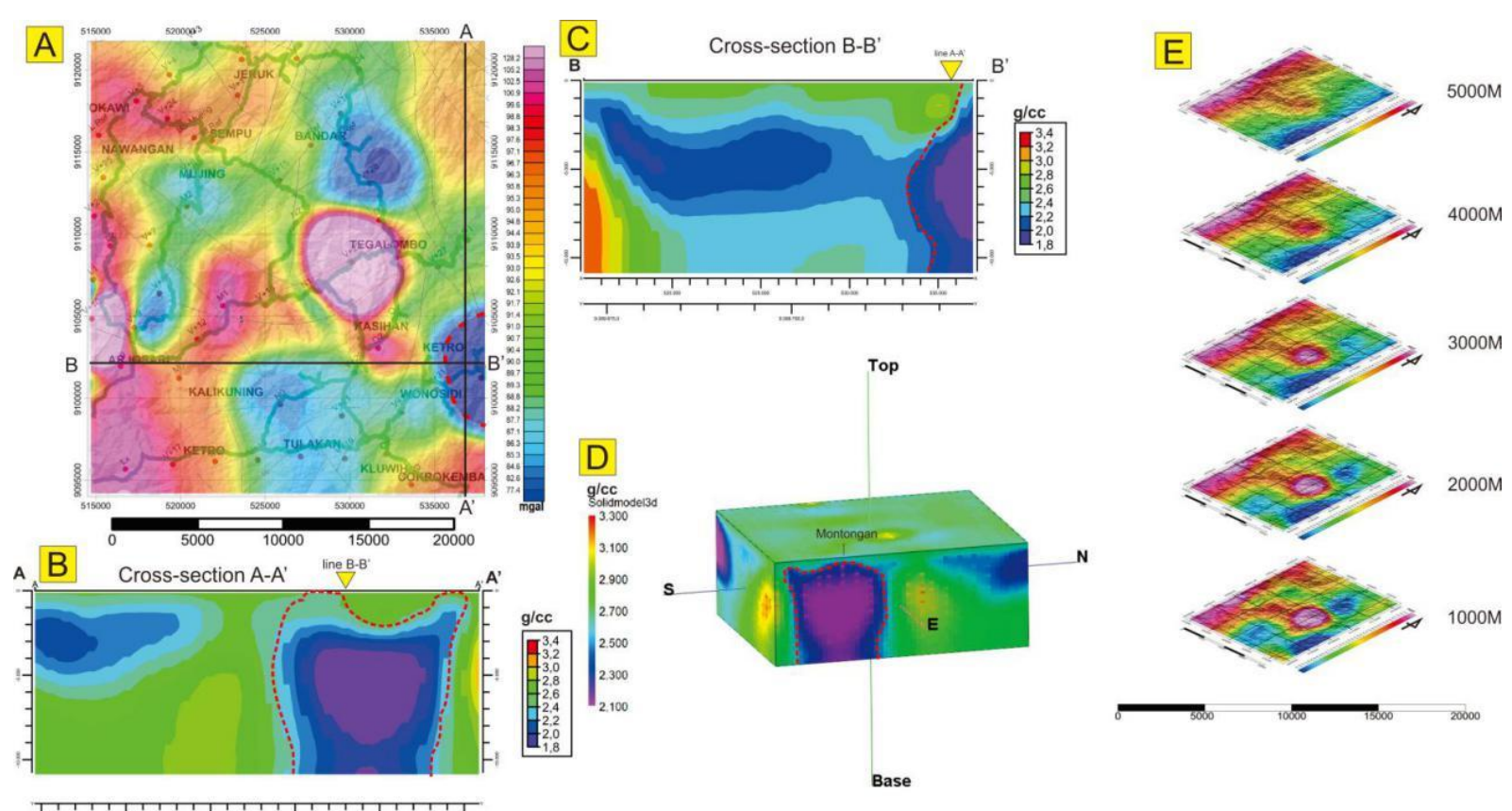

Figure 6. Gravity model of Pacitan District shows broad anomaly value. Complete bouguer anomaly map of Pacitan District (A), with two perpendicular cross section intersect each other showing density (B and C); The 3D model of density in Pacitan District (D), and Regional upward continuity with interval of $1000 \mathrm{~m}$ (E). All dashed red line indicates the interpreted body of Pacitan granitoid pluton.

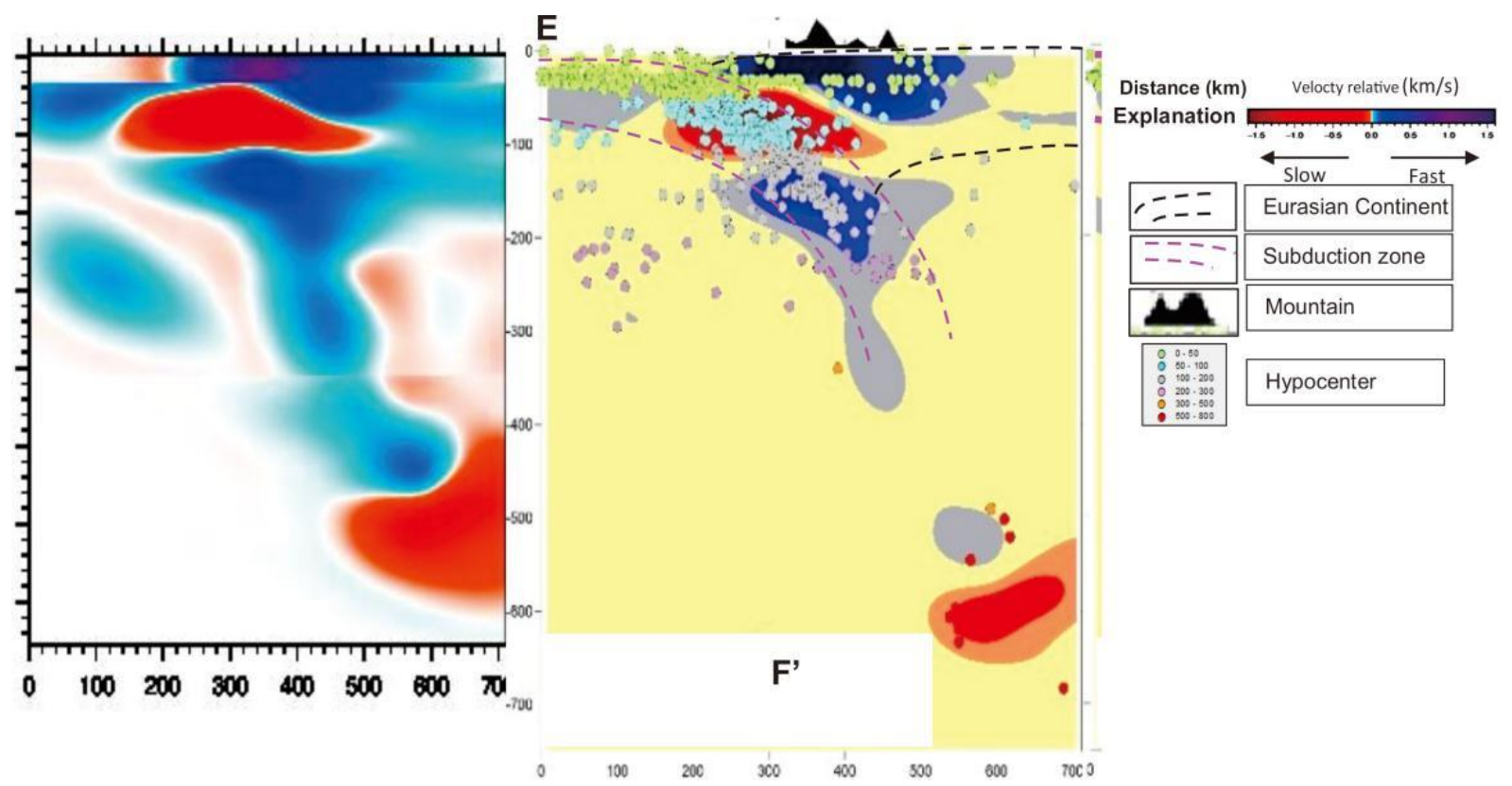

Figure 7. Seismic tomography model shows vertical section of N-S East Java section across Pacitan Area. The relative fast velocity wave (dark blue color) represents massive solid mass while low velocity wave (red color) represents ductile even liquid mass. Beneath Pacitan region, there are two solid mass which are override recent subduction and as part of the recent subduction zone (double red line).

\section{Discussion}


The distribution of Pacitan granitoid pluton was localized in within 7 x $5 \mathrm{~km}^{2}$ surrounds the area. The distribution in the surface is not well recorded due to high weathering intensity and covers the pluton's body. The rootless continuity of the interpreted pluton's body may explain that the plutons body seems to emerge from deep down beneath the thick.

Tomography also indicates the subsurface distribution of the interpreted pluton's body with the fast travel time (blue-clueish color), which may explain that the body did not really protrudes as if intrusion would be, however it might be part of a micro-continent that existing underneath East Java. According N-S section across Pacitan, it may extend up to $200 \mathrm{~km}$ wide but the densest part of the body beneath Pacitan may be $75 \mathrm{~km}$ wide. Another evidence that could support the argument regarding the part of continental fragment is the geochemical data that shows peraluminous $\mathrm{S}$ type granitoid. The very high alumina content are assumed to derived from the partial melting of the aluminum-rich meta-sedimentary rock from the thickening crust which is took place before the orogenic event. The absolute data to really strengthen this argument is by providing the SHRIMP analysis from the zircon which might be proposed for the next step.

\section{CONCLUSION}

Pacitan granitoid is tholeiitic series of post orogenic S type peraluminous granitoid which available in limited surficial outcrop but geophysically it may extend subsurface downward, it might be a big granitoid batolith $\left(>100 \mathrm{~km}^{2}\right)$. According to tomography study, it overlays above recent subduction zone. It may consistent with previous idea which based on zircon distribution in Tertiary sediments states the existence of microcontinent beneath southern east java.

\section{ACKNOWLEDGMENT}

This research funded by first year Penelitian Unggulan Perguruan Tinggi (PUPT) Scheme of Kemenristek-Dikti. For this grant the authors have acknowledged.

\section{REFERENCES}

[1] H. Samodra, S. Gafoer, and S. Tjokrosapoetro, Peta Geologi Lembar Pacitan, Jawa Timur. Pusat Penelitian dan Pengembangan Geologi, 1992.

[2] S. Sartono, Stratigraphy and Sedimentation of The Eastern Most Part of Gunung Sewu (East Java), no. 1. Direktorat Geologi Bandung, 1964.

[3] J. Soesilo, "Geologi dan Studi Batuan Beku Daerah Pasar Montongan, Kecamatan Tulakan, Kabupaten Pacitan," UPN "Veteran" Yogyakarta, 1989.

[4] J. Soesilo, N. Prasetyo, A. Widyarini, Sutanto, H. Murwanto, and Sutarto, "Studi Atas Granitoid Tulakan, Kabupaten Pacitan, Jawa Timur," in Prosiding PIT IAGI Ke-37, 2008, pp. 113-126.

[5] R. Soeria Atmadja, R. C. Maury, H. Bellon, H. Pringgoprawiro, M. Polve, and B. Priadi, "Tertiary Magmatic Belts in Java," J. SE Asian Earth Sci., vol. 9, pp. 13-21, 1994.

[6] Sutanto, "Batuan Volkanik Tersier Di Daerah Pacitan Dan Sekitarnya," Majalah Geologi Indonesia Vol 18, p. 2, 2003.

[7] N. Kueter, J. Soesilo, Y. Fedortchouk, F. Nestola, L. Belluco, J. Troch, M. Walle, M. Guillong, A. V Quadt, and T. Driesner, "Tracing the Deposition History of Kalimantan Diamonds by Zircon Provenance and Diamond Morphology Studies," Lithos, vol. 265, pp. 1-18, 2016.

[8] R. Hall, "The Eurasian SE Asian Margin as a Modern Example of an Accretionary Orogen," in Earth Acretionary System in Space and Time, Cawood, P., the Geological Society, London, Special Publication, 2009, p. 318.

[9] C. Prasetyadi, E. R. Suparka, A. H. Harsolumakso, and B. Sapiie, "Eastern Java Basement Rock Study: Preliminary Result of Recent Field Study in Karangsambung and Bayat Area," in Proceedings JCS 2005-HAGI-IAGI-PERHAPI, 2005.

[10] Sribudiyani, N. Muchsin, R. Ryacudu, T. Kunto, P. Astono, I. Prasetya, B. Sapiie, S. Asikin, A. H. Lumakso, and I. Yulianto, "The Collision Of The East Java Microplate And Its Implication For Hydrocarbon Occurrences In The East Java Basin," in Proceedings of Indonesian Petroleum Association 29th Annual Convention, 2003, p. 12.

[11] H. Smyth, P. J. Hamilton, R. Hall, and P. D. Kinny, 
"The Deep Crust Beneath Island Arcs: Inherited Zircons Reveal a Gondwana Continental Fragment Beneath East Java, Indonesia," Earth Planet. Sci. Lett., vol. 258, pp. 269-282, 2007.

[12] R. Listyaningrum, F. Muhlis, J. Soesilo, and I. R. Palupi, "Subduction Zone in Java Island Using Primary Wave Tomography from Jacobian Relocation Method Based on Ak135 Velocity Model," in International Symposium on Earth Hazard and Disaster Mitigation, AIP Conference Proceedings 1857, 2016, pp. 20011-1-20011-6.
[13] W. R. Le Maitre, Igneous Rocks: A Classification and Glossary of Terms, 2nd Editio. Cambridge: Cambridge University Press, 2002.

[14] Maniar, D. Papu, Piccoli, and M. Phillip, "Tectonic Discrimination of Granitoids," GSA Bull., vol. 101, no. 5, pp. 635-634, 1989.

[15] B. W. Chappel and A. J. R. White, "Two Contrasting Granite Types," Pacific Geol., vol. 8, 1974. 